ISSN: $1984-2201$

Copyright @ 2002, Universidade Federal do Ceará

\title{
SPATIAL DIMENSION OF RELIGIOUS EXPERIENCE
}

\author{
CARVALHO, Caê Garcia ${ }^{\text {* }}$
}

(a) MSc in Geography. Federal University of Bahia (UFBA). ORCID ID: https://orcid.org/0000-0003-1112-6680. CURRICULUM LATTES: http://lattes.cnpq.br/7234560101345225

\section{(*) CORRESPONDING AUTHOR}

Address: UFBA - Rua Barão de Geremoabo, s/n, Campus Universitário de Ondina. CEP: 40170290 - Salvador (BA), Brasil. Tel: (+55 71) 32838569 E-mail: cae_garcia@hotmail.com

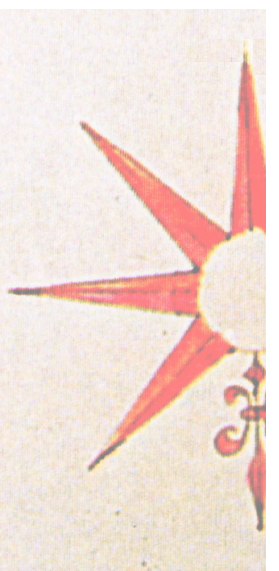

\begin{abstract}
This article discusses the spatial dimension of the religious experience between candomblecistas and evangelicals, which involves these agents' spatial practices and equally, their representations of space. This is done by establishing a parallel between Mythical Geography and Prophetic Geography with Candomblé (Terreiro do Cobre) and Neo-Pentecostalism (Universal Church of the Kingdom of God), respectively. These geographies (Mythical and Prophetic) were described by Dardel (2015) and express various ways of human beings relating to the Earth. It is these modes of relationship with space - synthesized in the concept of geographicity - that are discussed based on distinct creeds in which different ways of perceiving, representing and acting in reality are presented through two symbolic forms (CASSIRER, 1994), that of myth - which substantiates a Mythical Geography - and that of religion - which in turn gives rise to a Prophetic Geography.
\end{abstract}

Keywords: Mythical Geography and Prophetic Geography; symbolic form; geographicity; Terreiro do Cobre and Universal Church of the Kingdom of God.

\section{RESUMO / RESUMEN}

\section{EXPERIÊNCIAS RELIGIOSAS E DIMENSÃO ESPACIAL}

Pretende-se discutir neste artigo a dimensão espacial da experiência religiosa entre candomblecistas e evangélicos, o que envolve as práticas espaciais destes agentes e, igualmente, suas representações acerca do espaço. Esta tarefa será realizada estabelecendo-se um paralelo entre a Geografia Mítica e a Geografia Profética com o Candomblé (Terreiro do Cobre) e com o neopentecostalismo (Igreja Universal do reino de Deus), respectivamente. Tais geografias (Mítica e Profética) foram descritas por Dardel (2015) e expressam variados modos de relacionamento do ser humano com a Terra. São esses modos de relacionamento com o espaço - sintetizados no conceito de geograficidade - que se pretende discutir com base em distintos credos em que entram em cena maneiras diferenciadas de percepcionar, representar e agir na realidade sustentadas através de duas formas simbólicas (CASSIRER, 1994), a do mito - o que substancia uma Geografia Mítica - e a da religião - o que dá origem, por sua vez, a uma Geografia Profética.

Palavras-chave: Geografia Mítica; Geografia Profética; Forma simbólica; Geograficidade; Terreiro do Cobre e Igreja Universal do Reino de Deus.

\section{DIMENSIÓN ESPACIAL DE LA EXPERIENCIA RELIGIOSA}

En este artículo tenemos la intencíon de discutir la dimensíon espacial de la experiencia religiosa entre los miembros del Candomblé y evangélicos, lo que implica las práticas espaciales de estos agentes y, igualmente, suyas representaciones del espacio. Esta tarea se cumplirá estableciendo un paralelo entre la Geografía Mítica y la Geografía Profética con el Candomblé (Terreiro do Cobre) y con el neo-pentecostalismo (Igreja Universal do Reino de Deus), respectivamente. Tales geografías (Mítica y Profética) fueron descritas por Dardel (2015) y reflejan diferentes formas de relaciones de los seres humanos con la Terra. Son estos modos de relación con lo espacio - sintetizados en el concepto de geograficidade - que tenemos la intencíon de discutir con base en distintos credos, los cuales disponen de maneras diferenciadas de percibir, representar y actuar em la realidad sostenidas por dos formas simbólicas (CASSIRER, 1994), la del mito - lo que nos lleva a una Geografía Mítica - y la religion - lo que origina, por su vez, una Geografía Profética.

Palabras clave: Geografía Mítica; Geografía Profética; Forma simbólica; Geograficidad; Terreiro do Cobre y Igreja Universal do Reino de Deus. 


\section{INTRODUCTION}

This article explores the concept of geographicity as expressed by Erick Dardel (2015), understood as the relationship between the individual(s) and the Earth. In other words, geographicity permeates and marks out the dimension of human experience that subjects (individually and / or collectively) acquire / maintain / construct with space.

In "his" History of Geography (one of the chapters of his famous book L'homme et la Terre [1952; first edition]) the author stresses that his study is not to be confused with either a history of the discovery of the Earth or a historiography of geographic thought. Indeed, his purpose is to understand the "enduring attitudes of the human spirit when faced with immediate and everyday reality, in correlation with the dominant forms of sensibility, thought and belief of an era or civilization" (DARDEL, 2015, p. 46; our emphasis). In this context, the author presents three geographies: the Heroic, the Unfurled Sails and the Scientific. Heroic Geography sees geographic space as a space to be discovered, with the appeal to adventures and the role of the hero in manifesting some distance from the power of myths, the power of the clan and tradition on the individual. The Geography of the Unfurled Sails, in turn, is itself a chapter of the predecessor, related to maritime expansion and the discovery of "new worlds". Finally, Scientific Geography is based on the knowledge of the terrestrial reality that was already being forged in the movements of discovery and that sought, precisely, to examine reality to know it in a rational, objective and universal way.

These geographies - it is certainly very interesting to continue exploring them, but unnecessary for the purposes of this article - make up the cited chapter of Dardel's work, concerned with understanding the relationship between Man and space and its interface, in these different geographical conceptions.

But in reality the items that inaugurate this chapter are Mythical Geography and Prophetic Geography, discussing this interface - the relationship of the being with the Earth - between "primitive" peoples and their mythical world, and those who have reached the theological conception of the one God.

The purpose of the present article is to present and retake these mythical and prophetic geographies by establishing a parallel between geographicity - the mode and result through which spatial experiences and perceptions of space take place - of the candomblecistas, devotees of Candomblé, (based on the Mythical view) and evangelicals (based on the Prophetic vision).

Thus, the perspective of this work can be said to be twofold: in the foreground, to discuss these two forms of relationship with the surrounding reality, determined by a given belief, and, on the other hand, to discuss how different agents (candomblecistas and evangelicals), in fact, empirically, experience space in different "geographies". After all, as Dardel reminds us:

These 'geographies' each link to a certain global conception of the world, to a central unrest, to an effective struggle against the 'dark background' of the surrounding nature. This history only makes sense if we understand that the Earth is not raw data to measure as it happens, but that an interpretation transits between Man and Earth, a structure and a 'horizon' of the world, a 'enlightenment' that shows the real in the real, a 'base' from which consciousness develops (DARDEL, 2015, pp. 47-48; (our emphasis)

In order to fully understand this quotation, it should be pointed out that "geography" or "geographies" refer above all to Man's relationship with the Earth, of the being with space, and not necessarily scientific knowledge - the task of scientific geography itself is to account for the plurality of relationships between the human element and the terrestrial surface.

The emphasis that the author gives the interpretation which marks the relationship of the human with the Earth, the core of this interface, is noteworthy. Here, Cassirer (1994, p. 74) postulates that space and time are the structure in which reality is contained and that one must "analyze the forms of human culture to discover the true character of the space and time of our human world", that is, 
to unveil these different "geographies" of which Dardel speaks, it is necessary to understand the key element of a society's culture and its groups. Furthermore, we will see how the conception of time for candomblecistas and evangelicals impacts on their relationship with space, in their "geographies" - or rather, in their specific geographies.

The empirical basis supporting the discussions herein, with the focus on differentiating between (spatial) practices and representations (of space) - the basic foundations of geographicity - for evangelicals and candomblecistas was discussed in the present author's dissertation addressing how these agents, members of the Terreiro do Cobre and of the Universal Church of the Kingdom of God, experienced and represented the neighborhood where their religious temples were located (in the Engenho Velho da Federação, Salvador-BA), pointing to the spatial dimension of religious experience (CARVALHO, 2016).

Belzen's warning (2009 [a]; 2009 [b]; 2010) regarding the danger of generalizations made from phenomena observed in private studies supported by a cultural perspective is worth emphasizing (the author is writing about Psychology, but his assertion can extend to all human sciences). Belzen reports that each case study has its own sphere and singularity, impeding generalizations. However, some considerations about the spatial dimension of religious experience, although based on specific agents - restricted groups of candomblecistas and evangelicals - allow for deliberations that extrapolate the particularism of the Universal Church and the Terreiro do Cobre and extend to Christian religions (with a greater emphasis, in reality, between the Pentecostal and Neo-Pentecostal strands) and Candomblé as a whole.

The possibility of making these generalizations regarding the subject's relationship with the Earth is justified because these religious groups' spatial experiences and representations of space are sustained through the cohesion of religious belief, as dealt with below. We will begin by presenting Mythical and then Prophetic Geography, followed by an in-depth discussion of the way of life and experience of the candomblecistas and evangelicals.

The first step, however, is the understanding of myth and religion as symbolic forms of structuring and explaining human reality, following Cassirer's approach.

\section{RELIGION AS A SYMBOLIC FORM}

The aforementioned philosopher's words cited above show that to understand human existence it is necessary to reveal and explain the actual culture in which it is inserted. This is because, in humanity's evolutionary scale, when natural selection endowed humans not only with physical-corporeal features, but also cognitive ones (VALLE, 2001), man ceased to live in a merely physical universe and began to inhabit a symbolic universe. Language, myth or religion, science and art are parts of this universe, and are, therefore, symbolic forms of structuring reality:

[The forms described make up] the various threads that weave the symbolic network, the tangle of human experience. All human progress in thought and experience is refined by this network, and strengthens it. Man can no longer see [reality], so to speak, face to face [...]. In a sense. Instead of dealing with things themselves, man is constantly talking to himself. Having become so enveloped in linguistic forms, artistic images, symbols, or religious rites man cannot see or know anything except by the interposition of this artificial medium. This situation is the same both in the theoretical sphere and in practice. Even in the latter, man does not live in a world of naked and raw facts, or according to his immediate needs and desires. Man lives in the midst of imaginary emotions, hopes and fears, illusions and delusions, in his fantasies and dreams. 'What disturbs and frightens man,' said Epithet, are not things, but his opinions and fantasies about things' (CASSIRER 1994: p. 48-49).

This is the approach to be followed to understand the foundations of Mythical Geography and Prophetic Geography. We are interested in asking how these symbolic forms create this "arti- 
ficial medium" that explains and unveils, allowing the understanding of reality. Here there is the linkage of these arguments with the concept of culture, since it is essentially semiotic and therefore symbolic. According to Geertz (2008: p. 64), culture denotes a historically transmitted pattern of meanings, embodied in symbols and sustained by "a system of inherited conceptions expressed in symbolic forms through which men communicate, perpetuate and develop their knowledge and activities in relation to life".

This is the context of the discussion of how such symbolic forms - myth and religion - correlate with a specific geographicity in the ways candomblecistas and evangelicals experience and perceive space, based on different "lenses" in their ways of seeing, living and representing reality.

Now it is possible to specify our thinking when it comes to religious experience. Undoubtedly, as Amatuzzi (2004: p. 91) asserts, "religion refers to what is most basic in our psychic structures. For it concerns, if not necessarily a God, certainly something ultimate" (our emphasis), the universal character of religious experience (MASSIMI, 2004). This experience, related to an ultimate reality was qualified by Boulad (whose work is analyzed by Amatuzzi): the depth of oneself, the source of one's being, the center of everything, absolute transcendence and total immanence, a presence that fills everything, among other descriptions. These expressions, it may be said, "point more to a content of experience than to elaborate concepts. They almost suggest more than they designate" (AMATUZZI, 2004, p.101).

They almost suggest more than they designate because this is not properly the conceptual or representational sphere, rather that of experience (in spite of the relationship between both), experience based on absolute transcendence. It is, therefore, the experience of the sacred - which incarnates even the ultimate reality, the ultimate end, pointed out by religious systems. The sacred is, after all, the foundation of religion, its basis and its spirit. Thus, when we speak of the spatial dimension of religious experience we are seeking to establish a relationship between the sacred, the experience of the religious group under the auspices of the sacred that is and feeds the ultimate reality presented by religion and space. In other words, and more directly, we seek to verify how the sacred permeates and marks a particular relational mode of its adherents with the Earth, creating specific geographies manifest in spatial practices and representations of space from such religious experiences.

Before entering one of the main points of this article and discussing mythical and prophetic geography, it is worth noting that no value judgment is attributed to the distinction between myth and religion, in the sense of assessing what would be the best form of worship. Although Cassirer argues that any myth has a built-in morality, the author draws a distinction - as we shall see in greater detail later - between these two symbolic forms and states that only religion relies entirely on the moral problem of good and evil, and therefore considers religion morally and spiritually superior to myth.

Certainly there is some degree of reason in Cassirer's argument when he refers to the action itself and the divine / malign touch of chance, ${ }^{1}$ but perhaps there is a bias based on Western-Christian culture in his approach that confuses the actual problem of morality. If Candomblé does not present the problem of good and evil, right and wrong as concisely as Christianity- as evidenced, for example, in the Ten Commandments - this does not mean that there are no established ethics and

(1) "In its original and literal sense, the taboo seems to mean just one thing that is marked - which is not on the same level as other common, profane and harmless things [...]. Such danger has often been described as being supernatural, but it is by no means moral. If differentiated from other things, this differentiation does not mean a moral discrimination, and does not imply a moral judgment" (CASSIRER 1994: p. 172). When myth gives way to religions, they do not alter the taboos themselves, but the motives behind them. In the original system these motives were wholly irrelevant: "a thing belonging to this field is marked, but it is only the distinction itself, not the direction of it, which gives it its special mark. It may be taboo for its superiority or inferiority, its virtue or its vice, its excellence or its depravity", in which "the danger of becoming taboo is a physical danger. It is entirely beyond the reach of moral powers. The effect is the same in the case of an involuntary or voluntary act [...] [in which] the mode or intention of the approach does not count" (CASSIRER, 1994, p. 176-176). To religions, "the ideal of purity means something totally different from all previous mythical conceptions. Searching for purity or impurity in an object has become impossible [...]. The only purity that has meaning and dignity from the point of view of religion is the purity of the heart" (CASSIRER, 1994, p. 177). 
morality that, like Christian religions, are based (in their own way and according to the religious vision inherent in their creeds) on the leading problems of the community and human well-being.

In the same way, when we say that Candomblé provides a mythical interpretation of the Earth, a mythical Geography and approaches the symbolic form of myth - and the examples provided $a$ posteriori will evidence this parallelism without leaving doubts about this relationship - it is not the intention to delegitimize such a creed in any way or to subsume that it is not a religion, but magic, witchcraft, myth, macumba, etc., as it is unfortunately still often treated by society.

\section{MYTHICAL GEOGRAPHY}

We have seen that each symbolic form "rearranges" reality according to its interpretative framework and, in the mythical view, its world is a dramatic world of physiognomic qualities (CASSIRER 1994: p. 128). Let us explain such a conception through a contrast with scientific behavior. In general terms, the attempt is to discriminate reality and its objects from fixed, determined qualities, distinguishing what is accidental or substantial, essence or appearance, etc., in the compass of classification and systematization.

This analytic process is in clear opposition to the structure of perception and mythical thought, according to Cassirer. Here, reality is a world of actions, forces, conflicting magical powers - and in every worldly phenomenon the collision and action of these powers is made explicit, conditioning it. That is why

Mythical perception is always imbued with these emotional qualities. All that is seen or felt is surrounded by a special atmosphere - an atmosphere of joy or grief, of anguish, of excitement, of exultation or depression. 'Things' cannot be spoken of as dead or indifferent matter. All objects are benign or malignant, friendly or hostile, familiar or strange, attractive and fascinating or repellent and threatening (CASSIRER 1994: 128-129).

It is because of this perception, which is never indifferent and rationalized (in scientific terms, for even myth is not devoid of rational components), that myth adheres to the physiognomic qualities of objects - as an expression of supernatural powers - conditioned by mythology itself, which, as a symbolic form, supports the interpretation of the world and confers these qualities on reality.

Each and every object, as well as the human community, participate in this relationship in which magical (supernatural) powers and forces are evoked because everything and everyone participate in the unity of life. This unity of life is made possible by the religious (mythological) conception that both in humans and in nature - in stones, rivers, plants, animals, etc. - there is a magical-divine energy that enables the fruition of life. At this point, a first approximation can be made between the mythical interpretation and Candomblé, since the latter also has as a basis of its religious system the belief in the unity of life permeated and made possible by axé - a "magical fluid that has no form, but is felt, and which gives life and form to everything that exists" (BENISTE, 2004, p. 278). These words are almost identical to those of Durkheim [1996] when describing Mana - the same principle of the unity of life - in Australian tribes in his classic study The Elementary Forms of Religious Life.

This unity is one of the strongest and deepest impulses of mythic thought, in which this belief system "can only function in the context of the radical perception of the unity of things" (AMATUZZI, 2004: p. 95). Since the sacred principle pervades the whole sphere of life (mana or axé, for example), "man not having a prominent position in society", is part of it "but is in no respect superior to any other member" (CASSIRER, 1994, p. 139) (and, again, by the way, there is a striking parallel to the religious values of Candomblé). Thus, the scientific division into "territories" separated from one another, in which the kingdoms of plants, animals, and man are distinct, taking into account the differences between species, families and genera, is rejected by mythical thought. "Life is not divided into classes and subclasses. It is felt as a continuous whole that does not ad- 
mit precise and clear distinctions"2 (CASSIRER, 1994, p. 136) In other words, "its view of life is synthetic, not analytic" (ibid.).

Geographically this is revealed in multiple aspects and we begin by discussing the one related to this dramatic world that involves man and conditions him, including his subjectivity:

[...] it is man who feels and sees himself as an object: a product or plaything of forces that manifest themselves to him in his environment, and over which he rules with his magic and his rites. Even emotional and affective states, such as fear, jealousy or love, seem to him as the infusion of some diffuse power from his surroundings and that invades him from the outside. And it's there, to this exterior full of life and power, that he transports himself naturally, distancing from himself to observe himself, to get a foothold on a being that is stronger, more durable and more 'essential' than himself (DARDEL, 2015, 50- 51; our italics).

From this perspective, in the mythical universe, the Earth is the origin. It is the source of life, from where men emerge, as well as their divinities and demons. However, the Earth is not only the origin, it is also a presence: "Human reality updates itself as a possibility, summoning the being from the ensemble of the presences that surround it" (DARDEL, 2015, p. 52). Those that make up the dramatic world of the mythical vision, as Cassirer puts it, and "the Earth manifests itself as an update that never ceases to renew itself due to the virtue of the eternalizing ${ }^{3}$ function of the world" (ibid.).

The Earth as origin and presence has a particular incidence, therefore, in the mode of existential relationship with geographic reality, as will be examined below in the discussion of spatial practices and the representations of space for the povo de santo (people of the saint). Still in relation to this original relationship with the Earth - which lasts after death, making itself present in the earthly community -seen as the "Mother of all that lives, of all that is," according to Dardel $(2015$, p. 49; emphasis added), which creates, one can stress again, this bond of kinship with all that surrounds it, with the other forms of life. In this context, where the earth is the key to existence, "coming to the world is to detach oneself from the earth, but never completely breaking the umbilical cord through which the earth nourishes man" (DARDEL, 2015, p. 48). In this conception, which is "more 'lived' than conceived" (ibid.), mythical space is always permeated by the dimension of living, of experience.

This experience is, however, collective and not individualized. This organic whole that makes up reality and dilutes the differences between humans and animals / plants is the same that underpins a cohesive union between the social-religious group. Hence one understands the words of Dardel when he affirms that "the Earth is the greater principle of the unit of the group, clan or tribe, the form and the condition of the man being-with", ${ }^{4}$ set in a precise geographical place fulfilling a cosmological function, in a world where 'the individual person has no 'existence,' where the individual is only part of a whole, a member of a clan", in which "the earth is the basis of the collective subject, the

(2) "The ethnologist Karl von den Steinen reports that the members of certain totemic clans of an Indian tribe claimed to be one and the same as the animals from which they originated: they expressly stated that they were aquatic animals or red parrots. Frazer relates that in the Dieri tribe in Australia, people spoke of the head of a totem which consisted of a special kind of seed as being the very plant that gives the seed" (CASSIRER 1994: 138). In a similar way, Berkenbrock (1999) brings the words of interviewees, pais de santo, who claimed to be the plant itself, the Orixá, not a representation in a symbolic prism, but concretely in the empirical plane.

(3) "Myth is by no means the narrative of an event occurring on a precise and unique date. It is absolute, exempt from time as a date or time. Essential, it encompasses all existing. This 'essence', a typical and exemplary reality, the various beings actualize it, repeat it and manifest it" (DARDEL, 2015, p. 52). This update of reality from an immemorial past that conditions it is also explicit in the conception of African time, vide the works of Duda Oliveira (2006) and Julvan Oliveira (2009) in a closer approximation of the mythical vision and Candomblé.

(4) There is an implicit reference here to Martin Heidegger's (2005) considerations when, in his discussions of the ontology of human reality, he asserts that one of the most elementary features of our existence is to being-with, the indelible condition of our own being. 
concrete support of permanent and invisible existence actualized in the living group (DARDEL, 2015, p. 56; our emphasis).

It is these elements of Mythical Geography that can be emphasized when the intention is to make the spatial dimension of religious experience explicit. The following section examines how such an interpretation is manifested geographically, in the empirical case of the povo de santo. To this end, we now present Prophetic Geography.

\section{PROPHETIC GEOGRAPHY}

According to Cassirer, the main distinction between the symbolic forms of myth and religion lies above all in the new facet of the Divine - its ethical character. The diffusion of the sacred interspersed in all things is abandoned (mana, axé, wakan, orenda, etc.), the anthropomorphic deities (with respect to the Greek religion) and this new religiosity is concentrated "on a single point, the problem of good and evil" (CASSIRER 1994: p. 164).

In the mythical world supernatural forces could be used for any purpose - benign or malignant (which also occurs in Candomblé) - and the very manipulation of the sacred depended on ritual knowledge itself and for itself. This malign vein and this absolutization of the ritual rules, that is, of its methodology, are attacked by the religions that have reached a theological conception of the One God, where the strictly ethical sense surpasses the magical sense /sentiment and man's whole life becomes an uninterrupted struggle for virtue, verified in his actions and thoughts. The divine is no longer sought or approached through magical powers, but by the power of the virtue of those who live morally according to the celestial precepts. As Cassirer (1994, p. 166) states, "there is no longer a single step in the practical daily life of man which is considered, in a religious and moral sense, insignificant or indifferent. Nothing can be left out in the battle between divine and demonic powers". These words are truly underlined by the religious vision of the members of the Universal church.

The distinction between what is good and evil lies in the readings of the prophets who announce and reveal God's wills. In relation to the mythical world, the monotheistic position is a true revolution that strikes at its bases. Drawing on the ideals of biblical prophecy, Dardel argues that

The inner requirements of biblical revelations destroy the frameworks of experience and the mythical conception of the world; it breaks the organic bond ${ }^{5}$ between man and the Earth [...]; it is no longer experienced as a presence, and from that fact it has lost its 'soul' (DARDEL, 2015, p. 67).

This "desacralization" of the world that accompanies monotheistic religions will reverberate geographically on the modes of perception and experience of reality. The destitution of this dramatic world removes it from the stage of conflicting powers, of magical beings; nature is no longer "the great and benign mother, the divine lap from which all life originates", but is conceived "as the sphere of the law and obedience to the laws" (CASSIRER 1994: p. 165).

On losing these attributes, the Earth ceases to be a presence, it has no "soul" nor any absolute value. It loses its components and the world itself is nothing more than passing:

The great upheaval that occurs in geographic reality, under the effect of prophetism, warnings, and promise is the temporalization of the Earth and concrete space. The concepts of creation, of incarnation, of apostolate, the proclamation of a new age, the prophecy concerning 'new heavens' and a 'new earth' alter the direction of the Earth in the temporal dimension. A 'hereafter' stands before the Earth, as a current reality [...], the place of a history, of a waiting (DARDEL, 2015, p. 68).

(5) Christian thought, for example, is opposed to that of Candomble in relation to nature, since man is the center and measure of all things, for "in the Christian tradition, sanctifying power is invested in man, vice-regent of God, more than in nature. The church does not adapt to the spirit of the Earth: it transmits spirit to its surroundings" (TUAN, 2012, p. 207). 
If in the mythical vision in general and, specifically, regarding Candomblé, the treadmill of time "moves backward more than forward" (RIBEIRO apud OLIVEIRA, 2006, p. 49, emphasis by the author), in the prophetic conception the modeling of the "golden age" follows another path, it goes forward, into the future, the hereafter, to fulfill the announced prophecy. Logically, one's place in this prophesied future is the fruit of the one's moral life.

Christianity indelibly presents this characteristic in its cosmology by promising the faithful heaven as a reward for actions on this temporal Earth. We believe that the Universal Church elevates and makes explicit this characteristic by focusing in its liturgy on the God / Devil polarity, good and evil, morality and its opposite.

Having made these general considerations on Mythical and Prophetic Geography, let us turn to the discussion about spatial practices and representations of space by the candomblecistas and evangelicals.

\section{THE SPATIAL DIMENSION OF RELIGIOUS EXPERIENCE}

This topic begins with the empirical analysis of the aforementioned case study on the experiences in the Engenho Velho da Federação district (Salvador-BA) and its representations (of the neighborhood itself) for candomblecistas of the Terreiro do Cobre and evangelicals of the Universal Church, correlating the respective symbolic forms of myth and religion. This is followed by some generalizations about the spatial dimension of the religious experience for the povo de santo and for the Christians, notably the members of the Pentecostal and Neo-Pentecostal strands.

We have seen how the symbolic form of religion dispels the presence that permeated the Earth in mythical thought. Nothing more than a passage, in Christianity, it can be said, it is another presence that dwells in it. If in the mythical world the divine and the dark forces tensioned the drama of worldly life, in the Christian tradition - taken to extremes by the Protestant and (neo) Pentecostal sects - the Earth is essentially profane.

Sin is the keystone of the preaching and life of these members. One must always be attentive and vigilant, every day and in every step taken, for the Devil is lying in wait for you, waiting for breaches in your morals, in your virtue - as can be seen in the quotation above from Cassirer (see page 11). And where does the Devil live? In the world! Or rather, the reverse, the world resides in him, it belongs to that spirit, as the Bible itself tells us and that has always been the basis of the interviewees' answer to the question "what does your religion say about the world, what does it represents?" - The world lies in the Evil One.

When Jesus announces his death - a death to the world that has always been - Peter, troubled, says to him, "God be merciful to you, Lord! This must never happen to you" to which Jesus replies, "Get behind me, Satan! You are an offense to me, because you are not thinking God's thoughts but human thoughts" (Mat., 16, 22-3). Satan here represents the world of men, after all, for Jesus himself the world is a trap and therefore He fears it. For this reason, He needs to speak of his death and, consequently, of his resurrection - a resurrection "which is not a return to life [a worldly one, one might say], a rebirth, after the death of the body. Resurrection itself is death: death for the exterior nature of the Law, which is life in the interior of faith, that is, of the consciousness (VITTIELLO, 2000, p.151; emphasis by the author).

If Neo-Pentecostalism exalts worldly wealth through Prosperity Theology, which preaches that if the believer has God in their life and is faithful in tithing, they will have a blessed financial life; the same cannot be said of space. There is a denial of the world's spatiality, it appears as a negative charge because of the Christian vision. Fernandes (2013, p. 73), when researching how Christian belief centers on behaviors and attitudes, affirms that for the "evangelical youth, the city is 
divided between spaces of salvation and perdition", spatial differentiation that allows the construction of territorial differentiations where one can circulate or not. However, except for the temples and places where the hand of the church extends, every space, a priori, is regarded as profane - in the worst sense that this word can acquire: belonging to the Devil and his horde of demons (in an almost poetic contrast, we shall see how space is seen as sacred in Candomblé). Only in this way can one understand the abstention from the world, from practices, from social involvement, from experiences that are outside of sacred spaces, namely, the religious temples. It is the Church (in the Universal's case) that commands and guides all its members' social life, feeding such abstinence from the world, as one interviewee comments when asked about which places she usually goes to have fun:

Have fun?! Nowhere. I don't feel like it, I won't lie (laughs). Sometimes even the girls from the Church call me (sic) to go out; I don't go to the beach anymore, I don't want to; I don't go to the zoo, these outings, so, none. It's just here [Church] and from here I go to the Cathedral [a Universal church temple] also for the three-hour meeting on Sunday (D. Carmelita [fictitious names are used; it was opted to use code names to preserve interviewees' identity]).

If the example of this lady best illustrates our point, her speech indicates that people from the Church also go on outings, as she is invited by friends from the Universal Church. However, this case is by no means unique and is the standard answer of all adult evangelical interviewees from this Church. This suppression of the world, the rupture of this essential bond which binds man to the Earth of which Dardel speaks, explains why these agents had the sacred space of their temples as their only topophilic bond. After all, by breaking the mythical vision, the prophetic conception sees the Earth as merely fleeting, no longer ingrained in divine presences:

In a reading of the outside world according to time [that is, the hereafter], the Earth appears as a temporary and somehow precarious reality, founded by a creative will, enlightened from the future, placed as a concern, surpassed in its provisional duration by the infinity of God, limited by another spatiality, which encompasses the notion of the 'heavens' as opposed to the Earth. It is in this atmosphere of biblical prophecy that terrestrial gains its meaning, as opposed to celestial, a reality subtracted from the dimensions and limitations of all types of terrestrial spatiality (DARDEL, 2015, p. 69; author's italics).

In Milton Santos' (2006) reasoning on a possible geographic object, the author goes through the contributions of Sociology. In discussing Durkheim's thought that human action crystallizes in physical objects, immaterial crystallizations would also exist, such as the law, customs, works of art, and so on. However, non-geographical social forms become, perchance, social geographic forms, according to the thinker from Bahia. Be it the law, custom, family, etc., they end up leading to some sort of geographic organization. Thus, if society creates both spatial and non-spatial forms, even these, directly also become geographic forms.

In our case, to a certain degree, this is manifest in a particular way. The symbolic form of the Christian religion - this non-spatial social form - does not manifest itself spatially, or rather: it emerges spatially by absence, with the "death" of space. The absence of space is its spatial manifestation. And this refers to the sacredness of religion, the experience of / with the sacred itself: if the holy refers to the highest, that which cannot be touched and even seen - God never reveals his face to his prophets - the sacred can be longed for, manipulated, destroyed and consumed. However, the sacred can also refer to "something execrable that must be rejected. Sacred can come to mean 'execrable, condemnable, sinister' (like the Latin sacer)" (TRÍAS, 2000, p 121). The denial of space, of the world - this execrable entity - is as sacred as life with Christ and they are not dissociated in this quest for eternal life in heaven next to God, the guarantee of (personal) salvation - the ultimate end appointed by Christianity. After all, there is no action without a place (CHAVEIRO, 2014) 
and the denial of the self, the sacrifice of the self, the crushing of the Ego - which sums up, for our interviewees, what it is to $b^{6}{ }^{6}$ Christian - only materializes with the renunciation of lived space, with the death of sociability.

Thus, in this connection, we emphasize the relationship between the "world" (according to evangelical vocabulary, hence the quotation marks) and space. The "world" designates that which does not "belong" to God, that which is immersed in "worldliness" - everything and anything that distances one from faith (parties, drinks, gambling, and, finally, a multitude of elements). A relationship with an effectively geographic character is a clear boundary because such actions, conduct and behaviors, that distract one from God, which do not conform to His precepts, require, as Chaveiro alerts, a spatial substrate to support them - thus making explicit the suppression of the space experienced by religious cosmology.

It should be added that these spatial practices, in fact, their abortion, are intimately related to these agents' perception of space. This perception is precisely that which is conferred by religious representation - in a fusion and feedback between the religious ideal and the structure of reality (SILVA; GIL FILHO, 2009), in which everyday life is felt, perceived and lived in interpretive (and therefore representational) molds of what their religion has to offer at the expense of worldly or even exceptional phenomena, hence the return to reality - and the world / space cannot appear other than profane.

With regard to the neighborhood of Engenho Velho, this entailed quite particular, or even curious, perceptions and feelings. Many of its members (the older ones) claimed to like the neighborhood and living there. The younger ones, almost completely, had a voracious contempt ${ }^{7}$ for the neighborhood. That's what Carmelita herself told us. ("I like to live here"), but when asked if the Engenho Velho had any special meaning for her, her answer was categorical: "for me, only the Universal." Even when there is no contempt (as in the case of the Church's teenagers) and there is minimal affection, there is a stark indifference to space, because religious representations attribute this with the negative charge of a profane place and a transitory reality.

For the candomblecistas, rooted in a different perception of reality and, therefore, also of living it, space in general and the neighborhood of Engenho Velho da Federação in particular emerges through other colors. As we have seen with regard to the mythic conception, and so with Candomblé, the Earth signifies origin and forms as the basis of its existential connection, as well as being full of presence - the benign and malignant powers of that dramatic world.

It is evident that the treadmill of time moves more backward than forward and the mythological past is the springboard propelling events of the present: from the ancestors we learn how to act in the present, they are the guardians of ethics and morality under which human conduct should take place (GIROTO, 1999) - perhaps indicating the ultimate end of Candomblé. This would corroborate with Dardel's statement about the eternalizing function of myth that sustains the world and is ceaselessly renewed.

We have also seen how the Earth, in the symbolic form of myth, emerges as the benign mother. In the case of Candomblé, this existential connection with the Earth found in the mythical conception contributes to two precise places. One is to mythical Africa itself, the land of the most distant ancestors and the Orixás.

(6) One notes an emptying of the identity of these agents: all that they were (or are) must be suppressed, rejected for life with Christ. The only exponent of the Self must be exclusively the religious identity.

(7) The justification for this is because belief in Prosperity Theology is much more catalyzed among young people than in their older peers (certainly a lifetime in the Church, with the Holy Spirit in their homes, and not enrichment of the majority of its members - since the population stratum that adheres to the [neo] Pentecostal strands are among the poorest strata [MARIANO, 2004] - dilutes the paradigm of wealth raised in Universal); the younger ones, with a lifetime ahead of them, have a greater spirit and possibility of social ascent. (School has a fundamental role for these believers, as noted in the study of Maria Montenazo [2006], with higher grades and less truancy among Evangelicals 
As Giroto (1999) points out, for African culture, the idea of time is not dissociated from the idea of place (a very geographical consideration, by the way) and this constant updating of tradition, from mythological time to the present group, this intermediation with the ancestors, with their Gods, is done in a place - the neighborhood of Engenho Velho and this is the second place that reassembles and underpins this existential connection with the Earth (in this case, for the candomblecistas of Terreiro do Cobre). This is the location of the social-religious group's history, and on the other hand, it is through it (the place) that there is interconnectivity with tradition, with the ancestors, with the Divine, that is, with the sacred itself; terrestrial and not celestial, in contrast to Christianity. Space as essentially profane (in the worst sense of the word) through the prism of the evangelicals of the Universal Church, finds a poetic contraposition as commented regarding the candomblecistas: space emerges as sacred in providing this intermediation. Therefore, the words of Dardel (2015: 48) are worth repeating: "to come into the world is to detach oneself from the earth, but without ever completely breaking the umbilical cord through which the Earth nourishes man".

In the face of the indifference of the elders and the displeasure of the young at the Universal, it is through this relationship that the dense topophílic tie that viscerally unites the candomblecista to the neighborhood of the Engenho Velho da Federação is understood, despite all its deficiencies and social ills (the absence of urban facilities: there are no squares, courts or playgrounds, general infrastructure problems, drug trafficking conflicts, etc.).

Another fundamental aspect of the mythical vision that applies to the religious conception of Candomble refers to the value given to the collective experience. We have seen that a notion of totality composes the reality permeated by axé in which everything and everyone is intrinsically interconnected. In the dialectic between ancestry and integration, an ethical foundation takes shape when we realize that tradition does not exist without ancestry. This, in turn, "is not an affirmation of the heroic, narcissistic I; in ancestry what counts is the history of a people, the symbolic arsenal acquired by it over the course of time. The story of the self is told by tradition "(OLIVEIRA, 2006, p.120; emphasis by the author). Thus, the self is part of a whole and is important precisely in that it composes this whole; so it can be said that there is no identity without ancestry if the history of the self is tied to the history of the ancestors.

It is only in this context where a global vision of the whole prevails, a look directed at the collective, integrated, and not at the self, based on the being-with, that we can understand the speech - simply exciting - of one of the candomblecistas interviewed:

In those terms that I asked, do you consider Engenho Velho a place? ${ }^{8}$ Yes, I do, regardless of anything it has its things... its positive and negative side, the neighborhood. I can't say that it only has negative, it has positive things as well. How would you summarize this affection for the neighborhood? I would summarize it like this: from my 26 years here, I won't leave here for anything. It has never crossed my mind to move from here, ever. I always try to improve my life here inside the neighborhood, I don't say “I'm going to leave the neighborhood", it never went through my head. I'm improving my life to stay here in the neighborhood. I'm fixing my house; you can see it there [she points the house] to stay here in the neighborhood. I didn't think "ah, I graduated, I'm going to do whatever and go..."No! I'm going to stay in the neighborhood, I've never had it in my head, so, "I'm leaving." People say, "Ah, you're going to go out and look for something better", but we can look for

(8) We provided a definition of place that merged Lefebvre's (2000) conceptualization of the lived space and the debate of Tuan (2012) on topophilia; we wanted to highlight the dimension of experience (lived space) and affection for this or that space (topophilia). Our definition followed in these terms: "places that bring you pleasure and indicate a pause; pause that means comfort, places where you feel good; but which also indicate movement, in the sense of freedom; finally, places where you identify, places that relate to your own life story". We asked the interviewees, if they had / lived in some space / place that presented the characteristics listed in this description of "place". It is worth pointing out that only one Evangelical (among 10 interviewees) genuinely framed the Engenho Velho neighborhood in this conceptualization, while only one candomblecista did not do so (equally, among 10 interviewees). 
an improvement in the place we were born, we don't need to leave the neighborhood to look for this improvement, the improvement is inside yourself... if you don't look for your own improvement, you will not find anywhere (Janaína, Ekedi).

This way of experiencing the neighborhood collectively contrasts sharply with the vision of Universal Church in which one notices the primacy of self, of the personal search; it is worth mentioning that the interviewee is a History graduate and certainly has (or may have) the means of living in another space in the city of Salvador, but we have just seen the ethics that guide her conduct. Since the worldview of the African religions is based on the understanding that if one is responsible for everything and everyone immeasurably (GIROTO, 1999) - after all, everything and everyone is inextricably linked to the Earth - changing becomes irrelevant, what is the point of changing if my people, my social-identity group, do not grow with me?

Contrasts between the two symbolic forms of representing and perceiving the world (myth and religion) logically lead to distinct ways of experiencing it, for they structure equally differentiated worlds. The ways in which a member of Candomblé represents space and lives in it and the way in which a Christian (at least in the case of the evangelicals analyzed herein, those of the Universal Church) does so, differ. Their way of relating to the Earth is reversed, they are distinct "geographies" that express a geographicity - that relationship of the self with space - particular to each social-religious group based on specific religious (sacred) experiences.

Having analyzed these considerations, let us turn to the possible generalizations that can be made about the spatial dimension of religious experience for Candomblecistas and Evangelicals.

With respect to Candomblé, in the methodology of the dissertation that feeds the present discussions, we value agents belonging to other terreiros than Cobre, because common values guide this religion and allowed us to glimpse a certain correspondence with regard to possible spatial practices and to the representations of space coined by the povo de santo marked by their cosmogony (the interviewees from other terreiros expressed ideas identical to those of Cobre).

Thus the representations of space and the ways of experiencing it, described in the case of Cobre - space as sacred while evoking the mythical dimension - are general aspects of the African religion and mark the spatial experiences of the povo de santo. The very sentiment that underlies this relationship - the topophilic ardor that prevails among the candomblecistas (of all the terreiros) for the Engenho Velho da Federação - is certainly a constant mark of the devotees of Candomblé with the districts where their terreiros are located, since they evoke and underpin this intermediation with the sacred.

In addition, the spatial practices and the representations of space by the evangelicals maintain components that surpass the particularism of the Universal Church. The question is a little more complex because, in the case of the evangelical strands, there is a miscellany of conceptions between the interpenetrating aspects of Protestantism (MORAES, 2010) and religious institutions have very similar components (although they are in distinct "institutional periods", which, in theory, would lead to differentiated values). This similarity, which could favor a generalization, in fact makes the question more nebulous, since in undertaking it (the generalization) we would be subsuming that a plurality of churches would be under the same judgment, a difficult idea to defend precisely because of the multiple forms between which the interrelations of the conceptions of the three strands - historical, Pentecostal and Neo-Pentecostal Protestantism - can take place.

With regard to the practices and representations of space, it can be said that the generalizable factors reside in a particular component. The restriction of practices, the abortion of sociabilities and the perception of space as profane (the representational sphere intimately tied to spatial experience, or rather its negation) as we have seen in the case of Universal Church is explained by the cosmogonic view of the world as profane, in which a polarity, a clash, between God and the Devil 
is explained (BESSA, 2006) - in which we must remember that the world lies in the Evil One. It is precisely in Christian institutions - independent of their institutional period, in spite of the ease of diffusion of such temples and the creation of new denominations that can follow variable paths in their preaching and values - that are solidly based on this polarity, in this denial of the world as a priori in the life of the Christian, that one can generalize the results discussed here: explicitly restricted spatial practices - because of the "world" - and space, such an execrable entity, is qualified / perceived as profane, not belonging to the things of God.

\section{FINAL CONSIDERATIONS}

It is not the intention, at the closing of this text, to give a brief summary of what this article was about. To conclude, we want to highlight Cassirer's (1994, 145-146) warning regarding the relationship between myth and religion. ${ }^{9}$ Where religion dominates, the components of the symbolic form of myth are not absent. Based on a dense historical analysis, the author postulates that myth is potential religion and this, in turn, contemplates aspects that also configure myth9. This indicates that there is a type of dialogue between these two symbolic forms.

We can go further than Cassirer and assert that this relationship is not one-way from myth to religion (when it would not simply annihilate all the components of the mythical vision). In fact, religion itself can turn to essentially mythical elements in its liturgy. This was one of the findings made with the empirical material from the aforementioned master's dissertation (CARVALHO, 2016), in which it is noted that the Universal Church - and the other Christian institutions that dogmatically refer to the God x Devil theme - makes the world a dramatic world, like the mythical conception. This dramatic world is the conflict between demons and God's agents - those who take His Word and act morally according to His command. The assertion that the symbolic form of religion strips the world of its particular drama in which the supernatural powers of all orders are evoked, is thus relativized. It can even be said that the world is a stage of a more piercing drama for evangelicals than for the candomblecistas (this is stated on the basis of interviews, in which this relationship of supernatural powers "directing the drama" was considerably less problematized for the latter than the former). Thus, when a musician became ill and could not attend a Church event, the reader can imagine who acted stealthily to stop God-directed actions (according to the statement of a leader at the Universal Church when the event was canceled). Larger spheres are also filtered through the drama of good versus evil: an entourage of pastors went to the National Congress in October 2014 to destroy the evil spirit that was causing the economic crisis in Brazil. It can be added, as Neto and Junior (2010, p. 776-777) do, that for many of these evangelicals Brazil is not a first-world country due to deviations from the way of the Lord, "such as the devotion to Our Lady of Aparecida and the great presence of African cults, making the country a territory where the Devil feels at home. "

However, such a drama does not make the Earth a presence in which an existential connection is weighed. This polarity, in fact, is evidenced by the very negation of it (of the Earth), because this drama only develops because the world is essentially profane.

\section{BIBLIOGRAPHIC REFERENCE}

AMATUZZI, M. O desenvolvimento da representação na religião. In: PAIVA, G.; ZANGARI, W. (Orgs.) A representação na religião: perspectivas psicológicas. São Paulo: Edições Loyola, 2004. p. 98-104.

(9) The very idea of totality evoked in the mythical vision is made present in the religious conception, albeit by other bases. If in the mythical world this whole was permeated and interconnected by the unity of life marked by mana (or similar conceptions as axé) and by the unfolding of the drama that evoked supernatural powers, for religion there is still a unity, but this is only fruit of the will and power of the Creator (CASSIRER, 1994). 
BELZEN, J. Cultura, religião e self-dialógico. Raízes e caráter de uma Psicologia Cultural Secular da Religião. Revista de Estudos da Religião, São Paulo, v. 9, n. 4, p. 30-52, dez. 2009 [a].

BELZEN, J. Psicologia Cultural da Religião: perspectivas, desafios, possibilidades. Revista de Estudos da Religião, São Paulo, v. 9, n. 4, p. 1-29, dez. 2009[b].

BELZEN, J. Para uma Psicologia cultural da Religião. Aparecida, SP: Ideias \& Letras, 2010. 485p.

BENISTE, J. Òrun - Àiyé. 4. ed. Rio de Janeiro: Bertrand Brasil, 2004. 336p.

BERKENBROCK, V. A experiência dos orixás. 2. ed. Petrópolis: Editora Vozes, 1999. 474p.

BESSA, D. A Batalha Espiritual e o Erotismo. Revista de Estudos da Religião, São Paulo, v. 6, n. 1, p. 39-49, mar. 2006.

BÍBLIA, N.T. Mateus. In: BÍBLIA. Português. A Bíblia Sagrada. São Paulo: Sociedade Bíblica do Brasil, 1993. p. 17.

CARVALHO, C. Entre práticas e representações. 2016. 229f. Dissertação (Mestrado em Geografia) Instituto de Geociências da Universidade Federal da Bahia, Salvador, 2016.

CASSIRER, E. Ensaio sobre o homem. São Paulo: Martins Fontes, 1994. 400p.

CHAVEIRO, E. Corporeidade e lugar. In: HOLZER, W.; DE OLIVEIRA, L. (Orgs.) Qual espaço do lugar?

São Paulo: Ed. Perspectiva, 2014. p. 249-280.

DARDEL, E. O homem e a terra. São Paulo: Editora Perspectiva, 2015. 159p.

DURKHEIM, E. As formas elementares da vida religiosa. Trad. Paulo Neves. São Paulo: Paulinas, 1996. FERNANDES, D. Juventudes, Geografia e religião. RA'E GA, Curitiba, v. 27, n. 1, p. 67-93, 2013.

GEERTZ, C. A interpretação das culturas. Rio de Janeiro: LTC, 2008. 226p.

GIROTO, I. O universo mágico-religioso negro-africano e afro-brasileiro. 1999. 410f. Tese (Doutorado em Antropologia) - Faculd. de Filosofia, Letras e Ciênc.Humanas da Univers. de São Paulo, São Paulo, 1999.

HEIDEGGER, M. Ser e o tempo. Trad. Marcia Schuback. 15. ed. Petrópolis, RJ: Vozes; Bragança Paulista: Editora Universitária São Francisco, 2005. 325p.

LEFEBVRE, H. La production de l'espace. 4. ed. Paris: Anthropos, 2000. 265p.

MARIANO, R. Expansão pentecostal no Brasil: o caso da Igreja Universal. Revista Estudos Avançados, São Paulo, n. 18, v. 52, p. 121-138, 2004.

MASSIMI, M. Representação do sagrado e dinamismo psíquico. In: PAIVA, G.; ZANGARI, W. (Orgs.) A representação na Religião: perspectivas psicológicas. São Paulo: Edições Loyola, 2004. p. 105-112.

MONTENAZO, M. Cultura religiosa protestante e rendimento escolar nas camadas populares: um estudo sobre as práticas socializadoras. São Paulo. 2006. 103f. Dissertação (Mestrado em Sociologia da Educação) - Faculdade de Educação da Universidade de São Paulo, São Paulo, 2006.

MORAES, G. Neopentecostalismo - um conceito-obstáculo na compreensão do subcampo religioso pentecostal brasileiro. Revista de Estudos da Religião, São Paulo, v. 10, n. 2, p. 1-19, jun. 2010.

NETO, G.; JUNIOR, M. A Sedução divina no neopentecostalismo. Revista Mal-estar e Subjetividade, Fortaleza, v. 10, n. 3, p. 757-786, set. 2010.

OLIVEIRA, D. Cosmovisão Africana no Brasil. Curitiba: Editora Gráfica Popular, 2006. 188p.

OLIVEIRA, J. Africanidades e educação: ancestralidade, identidade e oralidade no pensamento de Kabengele Munanga. 2009. 298f. Tese (Doutorado em Cultura, Organização e Educação) - Faculdade de Educação da Universidade de São Paulo, São Paulo, 2009.

SANTOS, M. A natureza do espaço. 4. ed. São Paulo: Editora da Universidade de São Paulo, 2006. 259p. SILVA, A.; GIL FILHO, S. Geografia da Religião a partir das formas simbólicas em Ernst Cassirer. Revista de Estudos da Religião, São Paulo, v. 9, n. 2, p. 73-91, jun. 2009.

TRÍAS, E. Pensar a religião. In: DERRIDA, J.; VATTIMO, G. (Orgs.) A religião. São Paulo: Editora Liberdade ltda, 2000. p. 109-124.

TUAN, Y. Topofilia.Trad. Lívia de Oliveira. Londrina: Eduel, 2012. 342p.

VALLE, E. Neurociências e religião: interfaces. Revista de Estudos da Religião, São Paulo, v. 6, n. 3, p. 
1-49, set. 2001.

VITIELLO, V. Deserto, éthos, abandono: contribuição para uma topologia do religioso. In: DERRIDA, J.; VATTMO, G. (Orgs.) A religião: o seminário de Capri. São Paulo: Editora Liberdade, 2000, p. 151-188. 